\title{
ANTICANCER ACTIVITY OF ARGEMONE MEXICANA L (FLOWERS) AGAINST HUMAN LIVER CANCER (HEPG2) CELL LINE
}

\begin{abstract}
PRABHAKARAN D ${ }^{1,2 *}$, SENTHAMILSELVI MM ${ }^{3}$, RAJESHKANNA A ${ }^{1}$
${ }^{1}$ Department of Chemistry, Periyar E. V. R. College (Autonomous), Tiruchirappalli, Tamil Nadu, India. ${ }^{2}$ Department of Quality Assurance, Chettinad Cement Corporation Ltd., Ariyalur, Tamil Nadu, India. ${ }^{3}$ Department of Higher Education, Joint Director of Collegiate Education, Tiruchirappalli, Tamil Nadu, India. Email: prabhakarandhanaval@gmail.com
\end{abstract}

Received: 20 July 2017, Revised and Accepted: 25 July 2017

ABSTRACT

Objective: To explore the anticancer activity of the flowers of Argemone mexicana L. against the human hepatoma cell line (HepG2).

Methods: In vitro anticancer activity was carried out to screen cytotoxicity effectiveness of the solid obtained from ethyl acetate fraction of $A$. mexicana L. flower extract at different concentrations against the HepG2 cell line. The MTT (methylthiazolyl diphenyl- tetrazolium bromide) assay for cell viability and markers is expected to confirm the cytotoxicity.

Result: Ethyl acetate fraction from the flower extract of $A$. mexicana L. was tested for its anticancer activity against HepG2 cell lines (liver cancer) at various concentrations by MTT assay. It was confirmed that the $\mathrm{IC}_{50}$ value of this sample was $72 \pm 1.7 \mu \mathrm{g} / \mathrm{ml}$ against liver cancer HepG2 cell line.

Conclusions: A. mexicana L. is a potential plant with anticancer activity. The isolation of the pure compounds and determination of the structure of individual compounds will be further performed.

Keywords: Argemone mexicana L., Anticancer activity , MTT assay, HepG2, Cytotoxicity.

(C) 2017 The Authors. Published by Innovare Academic Sciences Pvt Ltd. This is an open access article under the CC BY license (http://creativecommons. org/licenses/by/4. 0/) DOI: http://dx.doi.org/10.22159/ajpcr.2017.v10i10.20744

\section{INTRODUCTION}

The harmful tumors are one of the major and driving reasons for grimness and mortality in people for around the world, with roughly 14 million new cases in 2012 and have high effect in industrialized nations [1-3]. These days, disease is the second driving reason for death all around and was in charge of 8.8 million passings in 2015. Internationally, about 1 in 6 passings is because of malignancy [4]. This growing trend indicates the deficiency in the current cancer therapies, which include surgery, radiotherapy, and chemotherapy [5,6]. There is a basic requirement for hostile to tumor operators with higher viability and less symptoms that can be obtained at a reasonable cost $[3,7,8]$. In such manner, the hunt and advancement of new medications have expanded, and plant turned into a pertinent asset for the revelation of anticancer compounds [9,10]. Nowadays, more than $60 \%$ of the economically accessible anticancer medications are of normally root. Normally inferred against proliferative medications, for example, doxorubicin, bleomycin, daunorubicin, vincristine, mitomycin $\mathrm{C}$ and vinblastine assume an imperative part in therapeutic growth chemotherapy in various strong tumors, and hematological malignancies $[10,11]$.

Argemone mexicana L. (Family: Papaveraceae), commonly known as Prickly Poppy in English and Premathandu in Tamil found in Mexico, United States, India, Bangladesh, and Ethiopia but has widespread distribution in many tropical and sub-tropical countries. It occurs as wasteland and roadsides weed in almost every part of India [12-14]. In Mexico, the seeds are considered as a remedy to snake venom [15]. In India, the smoke of the seeds is utilized to alleviate toothache. The new yellow, smooth seed separate contains protein-dissolving substances compelling in the treatment of diuretic, mitigating, malarial fever, sickness, scorpion sting, warts, mouth blisters, wound recuperating, skin illnesses, tingles, jaundice, and a cure to different toxic substances [16-19]. Hence, there is a need to assess the potential effects of this plant. Keeping this in view, the present study has been undertaken to investigate the anticancer potential of the solid obtained from the ethyl acetate fraction from the flower $A$. mexicana $\mathrm{L}$.

\section{MATERIALS AND METHODS}

\section{Collection of flowers}

The new flowers of $A$. mexicana L. were gathered from Z. Suthamalli, Ariyalur (Dt), Tamil Nadu, India, amid the time of January and recognized by Dr. S. John Britto, Director. The Rapinat Herbarium and Center for Molecular Systematics (Authentication No. DP004 dated: 22/01/2016). St. Joseph's College (Campus), Tiruchirappalli, Tamil Nadu, India.

\section{Extraction and fractionation}

New flowers ( $3 \mathrm{~kg}$ ) of $A$. mexicana L. were extricated with $90 \%$ ethanol $(5 \times 500 \mathrm{ml})$. The joined alcoholic concentrate was packed in vacuo, and the fluid concentrate was progressively fractionated with petroleum ether $(60-800 \mathrm{C})(6 \times 250 \mathrm{ml})$, Peroxide free diethyl ether $(4 \times 250 \mathrm{ml})$ and ethyl acetate $(8 \times 250 \mathrm{ml})$. Petroleum ether portion and diethyl ether part did not yield any isolable material. Ethyl acetate derivation part on fixation yielded a dry powder which was broken up in dimethyl sulfoxide DMSO to get different focuses and were utilized for further review.

\section{In vitro anticancer activity}

Cell line and culture

HepG2 (liver) cell lines were obtained from National Center for Cell Sciences Pune (NCCS). The cells were maintained in Minimal Essential Media (MEM) supplemented with 10\% fetal bovine serum (FBS), penicillin $(100 \mathrm{U} / \mathrm{ml})$, and streptomycin $(100 \mu \mathrm{g} / \mathrm{ml})$ in a humidified atmosphere of $50 \mu \mathrm{g} / \mathrm{ml}$ of $\mathrm{CO}_{2}$ at $37^{\circ} \mathrm{C}$.

\section{Reagents}

MEM was purchased from HiMedia Laboratories, FBS was purchased from Cistron Laboratories, Trypsin, methylthiazolyl diphenyl- 
tetrazolium bromide (MTT), and DMSO were purchased from Sisco research laboratory chemicals, Mumbai. The various chemicals and reagents were gotten from Sigma-Aldrich, Mumbai.

\section{Principle of MTT assay}

The MTT (3-(4,5-dimethylthiazol-2-yl)-2,5-diphenyltetrazolium bromide) decrease test was the main homogeneous cell viability examine created for a 96-well organization that was reasonable for high throughput screening. The MTT tetrazolium test innovation has been broadly received and stays well known in scholastic labs as prove by a huge number of distributed articles. The MTT substrate is set up in a physiologically adjusted arrangement, added to cells in culture, more often than not at a last grouping of $0.2-0.5 \mathrm{mg} / \mathrm{ml}$, and hatched for 1-4 hrs. The amount of formazan (directly corresponding to the quantity of suitable cells) is measured by recording changes in absorbance at $570 \mathrm{~nm}$ utilizing a plate perusing spectrophotometer. Viable cells with dynamic digestion change over MTT into a purple shaded formazan item with an absorbance most extreme almost $570 \mathrm{~nm}[20,21]$. At the point when cells kick the bucket, they lose the capacity to change over MTT into formazan; accordingly shading development fills in as a valuable and advantageous marker of the viable cells. The correct cellular instrument of MTT lessening into formazan is not surely known, but rather likely includes response with NADH (the redox responses of nicotinamide adenine dinucleotide) or comparative decreasing atoms that exchange electrons to MTT. Theory in the early writing including particular mitochondrial proteins has prompted the supposition specified in various productions that MTT is measuring mitochondrial movement. The formazan result of the MTT tetrazolium gathers as an insoluble encourage inside the cells and additionally being stored close to the cell surface and in the way of life medium. The formazan must be solubilized preceding recording absorbance readings. An assortment of techniques have been utilized to solubilize the formazan item, balance out the shading, stay away from dissipation, and lessen obstruction by phenol red, and other culture medium parts. Different solubilization techniques incorporate utilizing: Fermented isopropanol, DMSO, dimethylformamide, sodium dodecyl sulfate (SDS), and mixes of cleanser and natural dissolvable. Fermentation of the solubilizing arrangement has the advantage of changing the shade of phenol red to yellow shading that may have less obstruction with absorbance readings. The $\mathrm{pH}$ of the solubilization arrangement can be changed in accordance with give most extreme absorbance if affectability is an issue; be that as it may, other test advances offer substantially more noteworthy affectability than MTT.

\section{In vitro assay for cytotoxicity activity (MTT assay)}

The cytotoxicity of the sample (A. mexicana L.) on HepG2 (liver) cell line was determined by the MTT assay. Cells $\left(1 \times 10^{5} /\right.$ well $)$ were plated in $1 \mathrm{ml}$ of medium/well in 24-well plates (Costar Corning, Rochester, NY). Following 24 hrs incubation, the cell achieves the conversion. Then, cells were incubated in the presence of various concentrations of the samples in $0.1 \%$ DMSO for $24 \mathrm{hrs}$ at $37^{\circ} \mathrm{C}$. After removal of the sample solution and washing with phosphate-buffered saline (pH 7.4), $200 \mu \mathrm{l} /$ well (5 mg/ml) of 0.5\% 3-(4, 5-dimethyl-2-thiazolyl)2,5-diphenyl-tetrazolium bromide (MTT) phosphate-buffered saline solution was added to cells. After 4 hrs incubation, $100 \mu$ l solubilization solution ( $\mathrm{pH} 4.7$ for $40 \%(\mathrm{v} / \mathrm{v})$ dimethyl ether in $2 \%(\mathrm{v} / \mathrm{v})$ glacial acetic acid and $16 \%$ (wt/v) SDS) were added. Viable cells were controlled by the absorbance at $570 \mathrm{~nm}$. Estimations were performed, and the fixation required for a half inhibition of viability $\left(\mathrm{IC}_{50}\right.$ ) was resolved graphically. The absorbance at $570 \mathrm{~nm}$ was measured with an ultraviolet (UV)-spectrophotometer utilizing wells without test containing cells as spaces. The effect of the samples on the proliferation of HepG2 was expressed as the \% cell viability, using the following formula:

$\%$ Cell viability $=\left(A_{570}\right.$ of treated cells $/ A_{570}$ of control cells $) \times 100$

Statistical analysis

All the data were reported as the mean \pm standard deviation. All statistical analysis was performed by means of one-way analysis of variance (ANOVA) and Student's t-test using GraphPad Prism statistical software package version 7.02. The $\mathrm{IC}_{50}$ concentration was ascertained from nonlinear relapse examination utilizing the GraphPad Prism programming with the condition: $\mathrm{Y}=100\left[1+10^{\left(\mathrm{X}-\mathrm{LogIC}_{\mathrm{C}}\right)}\right]$. Only a value of $\mathrm{p}<0.05$ and 0.01 was considered statistically significant.

\section{RESULTS}

In vitro assays (cytotoxic studies)

The anticancer activity of the A. mexicana L. flower was confirmed by MTT assay (Table 1; Figs. 1 and 2). MTT is considered to be a reliable assay to determine the extent of cell viability. The control HepG2 cells showed high proliferation that has been taken as $100 \%$. Test samples showed effective $\mathrm{IC}_{50}$ value against HepG2 (liver) cell line was found to be $72 \pm 1.7 \mu \mathrm{g} / \mathrm{ml}$. It induced cytotoxicity in a significant manner which implicit the damage to the membrane integrity of the cell when compared with control. The cytotoxicity was increased with increase in the concentration of the sample and near normal level was attained at various concentrations $(10,25,50,100$, and $250 \mu \mathrm{g} / \mathrm{ml})$ and the

Table 1: Cell viability (\%) of HepG2 cell line

\begin{tabular}{lll}
\hline Concentration $(\mu \mathrm{g} / \mathrm{ml})$ & Cell viability $(\%)$ & $\mathrm{IC}_{\mathbf{5 0}}(\boldsymbol{\mu g} / \mathbf{m l})$ \\
\hline Control & 100 & $72 \pm 1.7$ \\
10 & $84.06 \pm 0.67^{* *}$ & \\
25 & $71.17 \pm 1.00^{* *}$ & \\
50 & $57.33 \pm 0.88^{* *}$ & \\
100 & $41.25 \pm 0.58^{* *}$ & \\
250 & $28.11 \pm 1.00^{* *}$ & \\
\hline
\end{tabular}

Values are shown as for means \pm SD of triplicate. ${ }^{* *} \mathrm{p}<0.05$ and 0.01 compared with control (one-way ANOVA and t-test)

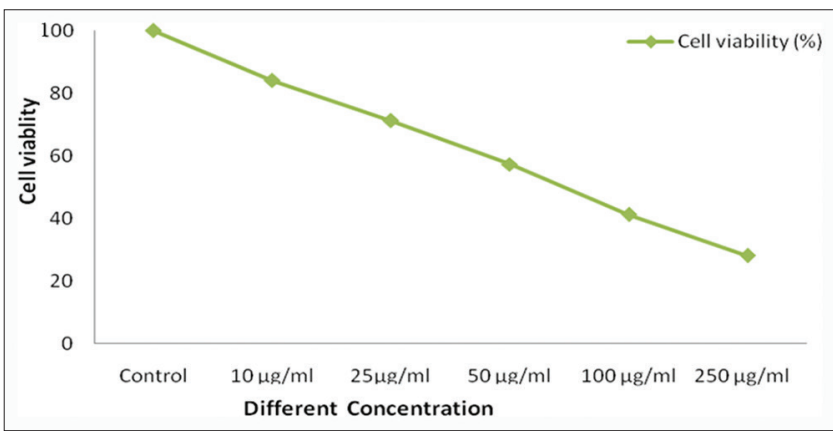

Fig. 1: Graphical representation of the cell viability (\%) values of the solid obtained from the ethyl acetate fraction of Argemone mexicana (flowers) against HepG2 cell line
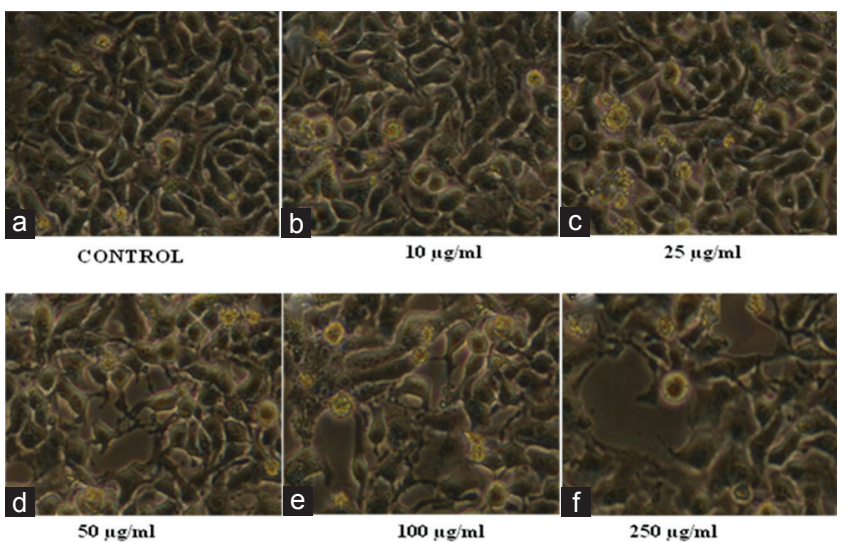

Fig. 2: (a-f) Effect of the solid obtained from the ethyl acetate fraction of Argemone mexicana flowers against human liver cancer HePG2 cell line in different concentration 
maximum effect was found when treated at $250 \mu \mathrm{g} / \mathrm{ml}$, which showed cell viability of $28.11 \pm 1.00 \%$. From the above results, it was confirmed that the solid obtained from ethyl acetate fraction of $A$. mexicana $\mathrm{L}$. extract at $250 \mu \mathrm{g} / \mathrm{ml}$ seems to offer significant protection and maintains the structural integrity of the hepatocellular membrane.

\section{DISCUSSION}

Horrible free radicals are created in the body amid ordinary digestion and furthermore on presentation to ecological toxins, for example, irresistible operator, UV light, and radiation etcetera. Destructive free radicals are not killed by the body's essential and optional resistance component on overabundance of ominous free radicals [21]. Existing clinical reviews have additionally demonstrated that supplemental levels of hostile to oxidant vitamins (E, C, and B complex) decrease, the individual hazard for certain disease [21-24]. Huge numbers of the restorative plant have been observed to be compelling in trial and clinical instances of growth. Therapeutic plants overwhelm immunomodulatory and hostile to oxidant properties, prompting against growth action [21,25-27]. This plant has been accounted for free radical rummaging impacts and antioxidant property [28,29]. In this study, the cytotoxic impact was expanded with the concentrate of the test sample (Fig. 2). From the results, the fraction had an $\mathrm{IC}_{50}$ value of $72 \pm 1.7 \mu \mathrm{g} / \mathrm{ml}$ which assumed cell viability $50 \%$. The United States National Cancer Institute (US-NCI) establishes that an extract or fraction that shows an $\mathrm{IC}_{50}$ value of $<100 \mu \mathrm{g} / \mathrm{ml}$ is considered active $[5,30,31]$. Hence, it is clear that the solid obtained from the ethyl acetate fraction of $A$. Mexicana L. flowers has cytotoxic effect against HepG2 cell line.

\section{CONCLUSION}

The outcomes acquired from the in vitro thinks about performed utilizing the HepG2 cell lines uncovers that the strong gotten from the ethyl acetate fraction of the $\mathrm{EtOH}$ concentrate of $A$. mexicana L. flowers has a direct anticancer action despite the fact that cell development restraint was expanded when grouping of the test was expanded. These fixations could prompt apoptosis on human malignancy cell lines, and its anticancer action was observed to be exact. In addition, work is required keeping in mind the end goal to build up the character of the substance constituent in charge of anticancer movement. Studies are in advance in our research facility to illustrate the subatomic structure of the compound. This contributes toward the advancement of intense anticancer medication.

\section{REFERENCES}

1. Ferlay J, Soerjomataram I, Dikshit R, Eser S, Mathers C, Rebelo M, et al. Cancer incidence and mortality worldwide: Sources, methods and major patterns in GLOBOCAN 2012. Int J Cancer 2015;136(5):E359-86.

2. Fukahori S, Yano H, Akiba J, Ogasawara S, Momosaki S, Sanada S, et al. Fucoidan, a major component of brown seaweed, prohibits the growth of human cancer cell lines in vitro. Mol Med Rep 2008;1(4):537-42.

3. Smyrniotopoulos V, Vagias C, Bruyère C, Lamoral-Theys D, Kiss R, Roussis V. Structure and in vitro antitumor activity evaluation of brominated diterpenes from the red alga Sphaerococcus coronopifolius. Bioorg Med Chem 2010;18(3):1321-30.

4. The Fact Sheet of World Health Organisation, February; 2017.

5. Tan W, Lu J, Huang M, Li Y, Chen M, Wu G, et al. Anti-cancer natural products isolated from Chinese medicinal herbs. Chin Med 2011;6(27):1-15

6. Alonso-Castro AJ, Villarreal ML, Salazar-Olivo LA, Gomez-Sanchez M, Dominguez F, Garcia-Carranca A. Mexican medicinal plants used for cancer treatment: Pharmacological, phytochemical and ethnobotanical studies. J Ethnopharmacol 2011;133(3):945-72.

7. Ma X, Wang Z. Anticancer drug discovery in the future: An evolutionary perspective. Drug Discov Today 2009; 14:1136-42.

8. Gumenyuk VG, Bashmakova NV, Kutovyy SY, Yashchuk VM,
Zaika LA. Binding parameter of alkaloids berberine and sanguinarine with DNA. Ukr J Phys 2011;56(6):524-33.

9. Kim J, Park EJ. Cytotoxic anticancer candidates from natural resources. Curr Med Chem Anticancer Agents 2002;2(4):485-537.

10. Mann J. Natural products in cancer chemotherapy: Past, present and future. Nat Rev Cancer 2002;2(2):143-8.

11. Sithranga Boopathy N, Kathiresan K. Anticancer drugs from marine flora: An overview. J Oncol 2010;2010:214186.

12. Mukherjee A, Namahata D. Medicinal plant lore of the tribals of Sundargarh district, Orissa. Ethnobotany 1990;1(2):57-60

13. Das PK, Misra MK. Some medicinal plants used by the tribals of Deomali and adjacent areas of Koraput district, Orissa. Indian J Forestry 1987; 10:301-3

14. Ibrahim HA, Ibrahim H. Phytochemical screening and toxicity evaluation on the leaves of Argemone mexicana Linn. (Papaveraceae). Int J Appl Sci 2009;3:39-43.

15. Bhattacharjee I, Chatterjee SK, Chatterjee S, Chandra G. Antibacterial potential of Argemone mexicana solvent extracts against some pathogenic bacteria. Mem Inst Oswaldo Cruze Rio de Janeiro 2006;101(6):645-8.

16. Chopra PN, Nayar SL, Chopra IC. Glossary of Indian Medicinal Plants (Including the Supplement). New Delhi: Council of Scientific and Industrial Research; 1986.

17. Prusti AB, Mishra A. Interesting medico-botanical claims by Khouds of Nayagarh district of Orissa. Plant Sci Res 2005;27(182):16-23.

18. Alagesaboopathi $\mathrm{C}$. Ethnomedicinal plants and their utilization by villagers in Kumaragiri Hills of Salem district of Tamilnadu, India. Afr J Tradit Complement Altern Med 2009;6(3):222-7.

19. Das GK, Murthy PN. Evaluation of Argemone mexicana Linn. Leaves for wound healing activity. J Nat Prod Plant Resour 2011;1(1):46-56.

20. Deepa M, Darsan MB, Ramalingam C. In vitro evaluation of the antioxidant, anti-inflammatory and antiproliferarive activities of the leaf extracts of Excoecaria agallocha L. Int J Pharm Pharm Sci 2015;7(11):346-52.

21. Priya PV, Radhika K, Kumar RS, Gowda BB, Beevi SS, Devi YP, et al. In vitro anti-cancer activity of aqueous and acetone extracts of Tridax procumbens leaf on PC 3 cell lines. Int J Pharm Pharm Sci 2011;3(4):1-4

22. Vinceti M, Dennert G, Crespi CM, Zwahlen M, Brinkman M, Zeegers MP, et al. Selenium for preventing cancer. Cochrane Database Syst Rev 2014;3:CD005195.

23. Pais R, Dumitraşcu DL. "Do antioxidants prevent colorectal cancer? A meta-analysis". Rom J Intern Med 2013;51:152-63.

24. Cortés-Jofré M, Rueda JR, Corsini-Muñoz G, Fonseca-Cortés C, Caraballoso M, Bonfill Cosp X. Drugs for preventing lung cancer in healthy people. Cochrane Database Syst Rev 2012;10:CD002141.

25. Ovadje P, Roma A, Steckle M, Nicoletti L, Arnason JT, Pandey S. Advances in the research and development of natural health products as main stream cancer therapeutics, Hindawi publishing corporation. Evid Based Complement Alternat Med 2015;751348:1-12.

26. Balachandran P, Govindarajan R. Cancer-an ayurvedic perspective. Pharmacol Res 2005;51(1):19-30.

27. Aggarwal BB, Prasad S, Reuter S, Kannappan R, Yadev VR, Park B, et al. Identification of novel anti-inflammatory agents from Ayurvedic medicine for prevention of chronic diseases: "Reverse pharmacology" and "bedside to bench" approach. Curr Drug Targets 2011;12(11):1595-653.

28. Perumal P, Sekar V, Rajesh V, Gandhimathi S, Kumar RS, Nazimudin KH. In vitro antioxidant activity of Argemone mexicana roots. Int J PharmTech Res 2010;2(2):1477-82

29. Goswami M, Yadav A, Bhardwaj R, Joshi YC, Sharma RA. Antioxidant properties of methanolic extract of Argemone mexicana. Res J Med Plant 2014;8(4):167-77.

30. Shabana MM, Salama MM, Shahira M, Ismail LR. In vitro and in vivo anticancer activity of the fruit peels of Solanum melongena L. Against hepatocellular carcinoma. J Carcinog Mutagen 2013;4(3):1-6.

31. Leyva-Peralta MA, Robles-Zepeda RE, Garibay-Escobar A, Ruiz-Bustos E, Alvarez-Berber LP, Gálvez-Ruiz JC. In vitro antiproliferative activity of Argemone gracilenta and identification of some active components. BMC Complement Alter Med 2015;15(13):532-8. 